\title{
Impacts of Four Invasive Asteraceae on Soil Physico-Chemical Properties and AM Fungi Community
}

\author{
Xinwei Chen1,2, Yuxiao Liu3 ${ }^{3}$, Hongmei Liu², Hui Wang², Dianlin Yang1,2, Chaohe Huangfu1,2* \\ ${ }^{1}$ College of Plant Protection, Shenyang Agricultural University, Shenyang, China \\ ${ }^{2}$ Agro-Environmental Protection Institute, Ministry of Agriculture, Tianjin, China \\ ${ }^{3}$ Institute of Information, Tianjin Academy of Agricultural Sciences, Tianjin, China \\ Email: huangfu24@163.com
}

Received 30 September 2015; accepted 27 October 2015; published 30 October 2015

Copyright (C) 2015 by authors and Scientific Research Publishing Inc.

This work is licensed under the Creative Commons Attribution International License (CC BY).

http://creativecommons.org/licenses/by/4.0/

(c) (i) Open Access

\begin{abstract}
Invasive Asteraceae are an important group of plants and might have universal impacts on invaded ecosystems. However, research data on the ecological impacts of specific plants are still lacking. Chromolaena odorata, Ageratina adenophora, Flaveria bidentis, and Mikania micrantha are four typical alien Asteraceae in China. The involvement of soil biota, in particular, the community structure of arbuscular mycorrhizal (AM) fungi in their invasion process was tested in present research. It was found that invasion by the four Asteraceae changed, to different extents, the nutrient levels in soils. Invasion by $C$. odorata, $A$. adenophora, and $F$. bidentis followed common patterns: 1) decreasing $\mathrm{pH}$ value; 2 ) increasing the soil AM fungal diversity and species richness. Invasion by all four Asteraceae tested increased nitrogen pools and accelerated nitrogen fluxes with a decrease in the phosphorus pool, especially available phosphorus. It was suggested that mycorrhizal symbiosis might partially promote successful invasion of these Asteraceae by affecting the metabolism of phosphorus in soil. The impacts on soil ecosystems of these Asteraceae tested were also species-specific, and different invasion strategies were exhibited.
\end{abstract}

\section{Keywords}

Invasive Plants, Mycorrhizal Symbiosis, Soil Nutrient Cycle, Enzyme Activity, Plant-Soil Interactions

\section{Introduction}

Biological invasions have gained increasing attention, and are recognized as a key problem for biodiversity ${ }^{*}$ Corresponding author.

How to cite this paper: Chen, X.W., Liu, Y.X., Liu, H.M., Wang, H., Yang, D.L. and Huangfu, C.H. (2015) Impacts of Four Invasive Asteraceae on Soil Physico-Chemical Properties and AM Fungi Community. American Journal of Plant Sciences, 6, 2734-2743. http://dx.doi.org/10.4236/ajps.2015.617274 
conservation. As the world's third largest country, China's territories cover several climatic zones from tropical to cold temperate. With its various habitats and environmental conditions, China is especially vulnerable to invasion by alien species [1]. Most of the 270 invasive plants identified in China are annuals; the next largest group is perennial herbs. The invasive species comprise 59 families in China, and the largest is the Asteraceae, which includes approximately $25.3 \%$ of all recognized invasive plants [2]. Plants in this family have similar biological traits because of their shared evolutionary history, and these traits benefit their invasive potential [3]. It is worthwhile exploring whether this important group of invasive plants, the Asteraceae, has any common ecological impacts or invasion strategies. Mikania micrantha, Chromolaena odorata, and Ageratina adenophora are typical of the alien Asteraceae that invade southern China. M. micrantha, a perennial vine ranked in the top 10 most invasive weeds in the world, has spread widely in China since the 1980s, and it has recently invaded many habitats, including forests, farmlands, wastelands, and orchards in southern China, causing significant damage [4]. C. odorata, a perennial forb native to the Americas from the southern United States to northern Argentina, is a major invasive plant of crops, plantations, savannas, and natural forests in many parts of the world, including tropical and subtropical areas such as central and western Africa, tropical America, India, the Philippines, southeast China, South Africa, eastern Indonesia, and Australia. In China, C. odorata is spreading rapidly, and can now be found in Yunnan, Guangdong, Guangxi, Hainan, Guizhou, and Taiwan Provinces, and Macao and Hong Kong, thus posing threats to local biodiversity and reducing the productivity of arable lands. A. adenophora, which is native to Mexico and Costa Rica, is a worldwide noxious invasive weed. This plant has invaded southern China since the 1940s and has become one of the most economically destructive invasive plants in China.

A new invasive weed, Flaveria bidentis (L.) Kuntze, is becoming an increasing problem in China. This species is native to South America, primarily Argentina, and was found for the first time in China in 2001. It outcompetes natural vegetation and forms a dense cover, and is widely distributed in Hebei, Shandong and Henan Provinces and Tianjin. This exotic weed prefers a warm and wet environment, but also has the ability to survive environmental stresses (salinity, barren soil, cold temperature), and evidence suggests that it has increased in abundance and range in some parts of China [5]. Invasion by this weed has brought on the degradation and disappearance of indigenous plant communities, and changed the structure and function of native ecosystems [6], seriously affecting the maintenance and stability of local biodiversity.

Arbuscular mycorrhizal (AM) fungi are ubiquitous root symbionts associated with over $80 \%$ of all extant terrestrial plants [7]. Through mutualism, AM fungi enhance nutrient acquisition for the host plant by transferring phosphorus and nitrogen captured from soil in exchange for carbon derived from photosynthate. AM fungi provide a key interface between the host plant and the soil mineral nutrients. AM fungal taxa exhibit host-specific growth responses [8] and further invoke different growth responses in host plants [9]. As host plants can shape distinctive AM communities even when inoculated with the same AM fungus [10], plant invasion seems likely to alter AM fungal communities [11]. The majority of alien invasive plants are mycorrhizal species capable of creating symbioses rapidly in a new habitat containing AM fungi. Researchers have recently proposed scenarios whereby AM fungi play a more significant role in the plant invasion process than have been previously thought [12] [13]. A positive feedback has been reported in mutualism between AM fungi and invasive plants, partly contributing to the successful invasion of alien plants. Until now, only Montesinos-Navarro et al. [14] have investigated phylogenetic host specificity in patterns of AM association and found no clear pattern for AM fungi in a semi-arid shrubland in Mexico. However, there are still limited data on the role of AM fungi in the plant invasion process, and much less is known of associations between closely related invasive plants and AM fungi [13].

Denaturing gradient gel electrophoresis (DGGE) has been extensively used to study the diversity and structure of AM fungal communities [15] [16]. The aim of this study was to test how different invasive Asteraceae species might influence the AM fungal status, and whether closely related invasive species hosted more similar AM fungal communities, either in diversity or abundance, than the existing native species. Such research may yield insights into the contribution of AM fungi to plant coexistence, plant diversity, and plant productivity [14] [17] [18]. The aims of the present study are 1) whether selected invasive plants within same genus have similar mycorrhizal symbiosis, and 2) whether their effects on soil ecosystem, especially related to AM fungi-plant interaction, are in common.

\section{Materials and Methods}

\subsection{Study Area}

The four Asteraceae species were collected from two wasteland ecosystems in northern and southern China. The 
study ecosystem invaded by F. bidentis was located in Xian County, Hebei Province (38¹5'30"N, 11557'50"E). The climate is a temperate continental monsoon, characterized by an annual average temperature of $12.3^{\circ} \mathrm{C}$, annual precipitation of $560 \mathrm{~mm}$, and annual average sunshine of $2800 \mathrm{~h}$. The soil is alluvial, weakly alkaline, relatively compacted, and mildly salinized. Other plants in the ecosystem were herbs such as Setaria viridis, Digitaria sanguinalis, and Phragmite saustralis. Because C. odorata, A. adenophora, and M. micrantha grow in the same ecosystem, only one control soil was selected. Samples were collected from Ruili, Yunnan Province (N24 03'577", E97 $\left.{ }^{\circ} 5^{\prime} 789 "\right)$, at an elevation of $794 \mathrm{~m}$. This area has a subtropical monsoon climate, with an annual average temperature of $21^{\circ} \mathrm{C}$, annual rainfall of $1394 \mathrm{~mm}$, and annual average sunshine of $2330 \mathrm{~h}$. Soil in this area is red loess and acidic. The native dominant vegetation is composed of Rabdosia stracheyi and Herba taraxaci, and the three invasive species are highly abundant. A sampling area $\left(500 \mathrm{~m}^{2}\right)$ was chosen within each ecosystem, to adequately cover the diversity of native plant species and areas completely colonized by the invasive plant species.

\subsection{Field Sampling}

Field sampling was conducted in the two different ecosystems as described above, and collections were made in August 17 and October 20, 2011 for F. bidentis and C. odorata, A. adenophora, and M. micrantha, respectively, corresponding with the period when invasives biomass reaches their peak. To verify the impact pattern found with those invasive plants, sampling was done in following year. Two sampling data was pooled for soil physicochemical parameters analyses and only once PCR-DGGE fingerprinting was presented given the fact that there were no inter-year differences between treatments detected. Two sampling areas were selected in each ecosystem. Sites were characterized as invaded when the invasive Asteraceae were the dominant species (>90\% in coverage), while the native sites were sites where only native vegetation was found. A total of 12 sampling plots $(1 \times 1 \mathrm{~m}$ quadrats) were distributed around each study area according to the presence or absence of invasive plants (six quadrats had a history of invasion by targeted plants for at least 5 years or more with a coverage of more than $90 \%$, and six quadrats were dominated by native grasses and devoid of invasive species). Invaded plots were placed inside of invasive Asteraceae patches which covered an area of at least $10 \mathrm{~m}^{2}$. Paired uninvaded plots were located between 2 and $5 \mathrm{~m}$ away so that they were not so close to the invaded plots that they would be invaded, but not so far that there would be obvious differences in light, moisture, or elevation.

The soil (at $0-15 \mathrm{~cm}$ in depth) in each quadrat was collected and mixed. Soil for microbial and enzyme activity analysis was frozen at $-20^{\circ} \mathrm{C}$ prior to analysis. Soil for measurement of physicochemical properties was kept dry until analysis. The aim of this study was to examine overall differences in AM fungal community composition between sites, so bulk soils were analyzed rather than rhizosphere soil to allow assessment of the potential shift in AM fungal communities caused by plant invasion.

\subsection{Analysis of Soil Physicochemical Properties}

Soil $\mathrm{pH}$ was determined using a 1:5 soil weight/water volume ratio and a $\mathrm{pH}$ meter. All soil nutrients were analyzed using conventional methods. Soil organic matter was measured using the $\mathrm{K}_{2} \mathrm{Cr}_{2} \mathrm{O}_{7}-\mathrm{H}_{2} \mathrm{SO}_{4}$ oxidation method. The Kjeldahl method was used for analyzing the total nitrogen $(\mathrm{N})$ content of the soil. Soil mineral $\mathrm{N}$ was extracted using $2 \mathrm{~mol} \cdot \mathrm{L}^{-1} \mathrm{KCl}$, then the concentrations of $\mathrm{NO}_{3}^{-}-\mathrm{N}$ in the $\mathrm{KCl}$ extracts were determined by hydrazine sulfate colorimetry and the concentrations of $\mathrm{NH}_{4}^{+}-\mathrm{N}$ by indophenol blue colorimetry. Total phosphorus (P) was extracted using the $\mathrm{HClO}_{4}-\mathrm{H}_{2} \mathrm{SO}_{4}$ method, and available $\mathrm{P}$ was determined using the sodium bicarbonate method. The urease activity was determined using urea as the substrate, and the soil mixture was incubated at $37^{\circ} \mathrm{C}$ for $5 \mathrm{~h}$. The residual urea was determined using a colorimetric method. Phosphatase activities were measured using the $p$-nitrophenol method, and potassium permanganate titration was used to determine peroxide dehydrogenase activity.

\subsection{Characterization of AM Fungal Community Structure}

Genomic DNA was extracted from approximately $0.25 \mathrm{~g}$ of soil using the Power Soil DNA isolation kit (MoBio Laboratories, CA, USA). Compositions of AM fungal communities were characterized using polymerase chain reaction (PCR)-DGGE. A nested PCR was used to amplify AM fungal DNA. $2 \mu$ DNA (10 ng) were subjected to an initial PCR as the template using the AM fungal specific primers AML1 and AML2 to amplify an ap- 
proximately $0.8 \mathrm{~kb}$ section of the small subunit rRNA gene. PCR was carried out using $0.2 \mathrm{mMdNTPs}, 0.2 \mu \mathrm{M}$ of each primer, $0.5 \mathrm{U}$ of TaqDNA polymerase (Takara Co. Ltd., China), and the manufacturer-supplied reaction buffer in a total volume of $20 \mu \mathrm{l}$. Initial denaturation was at $94^{\circ} \mathrm{C}$ for $3 \mathrm{~min}$, followed by 30 cycles at $94^{\circ} \mathrm{C}$ for $30 \mathrm{~s}, 50^{\circ} \mathrm{C}$ for $30 \mathrm{~s}$, and $72^{\circ} \mathrm{C}$ for $45 \mathrm{~s}$, followed by a final extension period at $72^{\circ} \mathrm{C}$ for $7 \mathrm{~min}$. PCR products were analyzed using $1.0 \%(\mathrm{w} / \mathrm{v})$ agarose gel electrophoresis. The first PCR product was diluted 1/20 with $\mathrm{ddH}_{2} \mathrm{O}$, and further employed as template DNA in a second PCR reaction using the universal eukaryotic primers NS31 [19] with a GC clamp (NS31-GC) and G101 [20]. The thermo cycling conditions were as described above, with the exception of the primer annealing at $54^{\circ} \mathrm{C}$ for $50 \mathrm{~s}$. The primers sequences were as described by Long et al. [21].

The PCR-DGGE was carried out using the DCode system (Bio-Rad, CA, USA) and following the manufacturer's instructions. The concentration of acrylamide gel (37.5:1) was 8\%; the denaturing gradient was 30\% - 50\% (100\% denaturant contained $7 \mathrm{M}$ urea and $40 \%$ (v/v) deionized formamide); and the electrophoresis buffer fluid was $1 \times$ TAE. $25 \mu \mathrm{L}$ of PCR product and $5 \mu \mathrm{L}$ of $6 \times$ loading buffer were mixed before adding this to the loading wells using a micro-injector. This was pre-run for $30 \mathrm{~min}$ at $70 \mathrm{~V}$ and $60^{\circ} \mathrm{C}$, and then electrophoresis was carried out for $15 \mathrm{~h}$ at $110 \mathrm{~V}$ and $60^{\circ} \mathrm{C}$. The gel was then removed, and immediately stained with SYBR ${ }^{\mathrm{TM}}$ Green I $(1: 10,000)$ (Invitrogen) for 28 min. Images of the DGGE profile were captured and recorded using the Gel Dox XR gel imaging system (Bio-Rad, USA).

\subsection{Statistical Analysis}

Quantity One software (Bio-Rad, USA) was used to analyze DGGE banding patterns by measurement of migration distance and intensity of the bands within each lane of a gel. The impacts of invasive plants on the community structure of AM fungi in soils were assessed using the Shannon-Wiener index $(H)$, the abundance index $(S)$ and the evenness index $(E)$. These indexes were calculated as follows: $H=-\sum p_{i} \ln p_{i}$ and $E=H / \ln S$, where $S$ is the abundance index, indicating the number of bands in the DGGE gel. $p_{i}$ corresponds to the proportion of the gray level of band $i_{\text {th }}$ in the total gray level of the sample. Comparisons of soil physicochemical properties and AM fungal community diversity indexes among sites were performed by means of one-way analysis of variance (ANOVA) and post hoc (least significant difference) tests. The DGGE pattern profiles were compared using pairwise similarity coefficient $(C s)$ analysis. The $C s$ values were calculated as follows: $C s=2 j /(a+b)$, where $a$ is the number of DGGE bands in lane $1, b$ is the number of bands in lane 2, and $j$ is the number of common bands. Dendrogram analysis was employed based on the Cs value. The relationship between soil AM fungi diversity index and selected soil physio-chemical parameters was assessed based on a Pearson correlation analysis. All other data analyses were conducted using SPSS 16.0 software.

\section{Results}

\subsection{Soil Physicochemical Properties}

In the soils invaded by $F$. bidentis, the organic matter and $\mathrm{NH}_{4}^{+}-\mathrm{N}$ increased by $69.8 \%$ and $\mathrm{NO}_{3}^{-}-\mathrm{N}$ by $68.26 \%$ when compared with the native soil (CK). Conversely, the total $\mathrm{P}$ and available $\mathrm{P}$ decreased significantly $(P<$ $0.05)$ after invasion by $F$. bidentis, but there was no significant change detected in total $\mathrm{N}$ or pH $(P>0.05)$ (Table 1).

In soils invaded by the other three Asteraceae, only the soil $\mathrm{pH}$ in sites with $M$. micrantha was remarkably higher than that in native soil. Total $\mathrm{N}$ and $\mathrm{NH}_{4}^{+}-\mathrm{N}$ were both significantly increased, and enhanced $\mathrm{NO}_{3}^{-}-\mathrm{N}$ was also found in the soils invaded by $M$. micrantha and $C$. odorata $(P<0.05)$. However, in soils invaded by $A$. adenophora a significant decrease was observed in available P (81.16\%) and similarly in sites invaded by

Table 1. Soil physio-chemical parameters of invaded and non-invaded blocks by Flaveria bidentis.

\begin{tabular}{cccccccc}
\hline Treatments & $\mathrm{pH}$ & $\begin{array}{c}\text { Organic matter } \\
(\mathrm{g} / \mathrm{kg})\end{array}$ & $\begin{array}{c}\text { Total } \mathrm{N} \\
(\mathrm{g} / \mathrm{kg})\end{array}$ & $\begin{array}{c}\mathrm{NH}_{4}^{+}-\mathrm{N} \\
(\mathrm{mg} / \mathrm{kg})\end{array}$ & $\begin{array}{c}\mathrm{NO}_{3}^{-}-\mathrm{N} \\
(\mathrm{mg} / \mathrm{kg})\end{array}$ & $\begin{array}{c}\text { Total P } \\
(\mathrm{g} / \mathrm{kg})\end{array}$ & $\begin{array}{c}\text { Available } \mathrm{P} \\
(\mathrm{mg} / \mathrm{kg})\end{array}$ \\
\hline CK & $8.23 \pm 0.53 \mathrm{a}$ & $5.98 \pm 0.19 \mathrm{~b}$ & $0.97 \pm 0.02 \mathrm{a}$ & $5.63 \pm 1.14 \mathrm{~b}$ & $4.60 \pm 0.94 \mathrm{~b}$ & $0.63 \pm 0.03 \mathrm{a}$ & $41.33 \pm 3.53 \mathrm{a}$ \\
F. bidentis & $8.18 \pm 0.06 \mathrm{a}$ & $7.35 \pm 0.42 \mathrm{a}$ & $0.99 \pm 0.01 \mathrm{a}$ & $9.56 \pm 1.11 \mathrm{a}$ & $7.74 \pm 0.90 \mathrm{a}$ & $0.57 \pm 0.03 \mathrm{a}$ & $6.27 \pm 0.65 \mathrm{~b}$ \\
\hline
\end{tabular}

The numbers are mean \pm standard errors (SE) with 6 repetitions. Data with different letter in the same column are significantly different at $P=0.05$. The same below. 
C. odorata (59.41\%). It was concluded that soil properties underwent significant changes in comparison with native soil after invasion by these plants, and that soils invaded by A. adenophora, C. odorata, and F. bidentis appeared to follow similar patterns (Table 2).

\subsection{Soil Enzyme Activity}

One-way analysis of variance indicated that invasion by $F$. bidentis led to increased enzyme activity in soils $(P<$ 0.05 , Table 3 ). Acidic phosphatase activity increased by $42.42 \%$, neutral phosphatase activity by $58.33 \%$, and alkaline phosphatase activity by $41.44 \%$, respectively.

Enzyme activities in invaded soils sampled in Yunnan Province were significantly different between M. micrantha, A. adenophora, C. odorata, and the native soils (Table 4). Urease activity, for example, was significantly higher in soils with $M$. micrantha and $C$. odorata than in native soils or those with A. adenophora. Acid phosphatase activity was only lower in soil invaded by $M$. micrantha $(P<0.05)$. Alkaline phosphatase activity showed no significant difference between soils with A. adenophora, those with $C$. odorata, and native soil, but was significantly increased in soils with $M$. micrantha. Catalase activity showed the same trend as alkaline phosphatase.

\subsection{Community Structure of AM Fungi}

The composition of AM fungi communities in F. bidentis and native soils were compared using PCR-DGGE. Gel profiles of 18S rDNA fragments of AM fungi are presented in Figure 1. The Cs between soil invaded by $F$. bidentis and native soil was $63 \%$, and a dendrogram created using hierarchical clustering analysis showed all samples clustered into two main groups, indicating a marked difference caused by plant invasion. Table 5 shows our calculations of species richness, the Shannon index, and the evenness index of AM fungal communities. The values for the diversity index $(H)$ and evenness index $(E)$ of AM fungi in invaded soil were significantly higher than those of the native control soil.

Table 2. Soil physio-chemical parameters of invaded and non-invaded blocks in Mikania micrantha, Chromolaena odorata and Ageratina adenophora plots, respectively.

\begin{tabular}{|c|c|c|c|c|c|c|c|}
\hline Treatments & $\mathrm{pH}$ & $\begin{array}{l}\text { Organic matter } \\
(\mathrm{g} / \mathrm{kg})\end{array}$ & $\begin{array}{c}\text { Total N } \\
\text { (g/kg) }\end{array}$ & $\begin{array}{l}\mathrm{NH}_{4}^{+}-\mathrm{N} \\
(\mathrm{mg} / \mathrm{kg})\end{array}$ & $\begin{array}{l}\mathrm{NO}_{3}^{-}-\mathrm{N} \\
(\mathrm{mg} / \mathrm{kg})\end{array}$ & $\begin{array}{l}\text { Total P } \\
\text { (g/kg) }\end{array}$ & $\begin{array}{l}\text { Available P } \\
\text { (mg/kg) }\end{array}$ \\
\hline CK & $4.98 \pm 0.13 b$ & $18.31 \pm 0.56 b$ & $1.16 \pm 0.02 \mathrm{c}$ & $9.69 \pm 1.31 b$ & $3.76 \pm 0.10 \mathrm{~b}$ & $0.41 \pm 0.01 \mathrm{a}$ & $35.82 \pm 0.59 a$ \\
\hline M. micrantha & $6.93 \pm 0.06 a$ & $13.98 \pm 0.73 d$ & $1.43 \pm 0.02 b$ & $12.36 \pm 1.63 a$ & $4.30 \pm 0.31 a$ & $0.38 \pm 0.03 a$ & $35.85 \pm 1.78 a$ \\
\hline C. odorata & $4.92 \pm 0.13 c$ & $16.93 \pm 0.52 c$ & $1.40 \pm 0.08 b$ & $14.15 \pm 0.55 a$ & $4.83 \pm 0.67 a$ & $0.28 \pm 0.02 b$ & $6.75 \pm 0.77 c$ \\
\hline A. adenophora & $4.91 \pm 0.10 \mathrm{c}$ & $20.82 \pm 0.60 \mathrm{a}$ & $1.63 \pm 0.05 a$ & $12.84 \pm 1.13 a$ & $3.86 \pm 0.66 b$ & $0.41 \pm 0.01 \mathrm{a}$ & $14.54 \pm 1.20 b$ \\
\hline
\end{tabular}

Table 3. Soil enzymatic activities in invaded and non-invaded blocks by Flaveria bidentis.

\begin{tabular}{|c|c|c|c|c|c|c|}
\hline Treatments & $\begin{array}{l}\text { Urease } \\
\text { (ug/g·h) }\end{array}$ & $\begin{array}{l}\text { Acid phosphatase } \\
\quad(\mathrm{mg} / \mathrm{g} \cdot 24 \mathrm{~h})\end{array}$ & $\begin{array}{l}\text { Neutral phosphatase } \\
\text { (mg/g.24h) }\end{array}$ & $\begin{array}{l}\text { Alkaline phosphatase } \\
\text { (mg/g.24h) }\end{array}$ & $\begin{array}{l}\text { Total phosphatase activity } \\
\text { (mg/g.24h) }\end{array}$ & $\begin{array}{c}\text { Catalase } \\
(\mathrm{mg} / \mathrm{g} \cdot 24 \mathrm{~h})\end{array}$ \\
\hline CK & $5.88 \pm 0.71 b$ & $0.19 \pm 0.05 b$ & $0.05 \pm 0.01 b$ & $0.65 \pm 0.21 b$ & $0.89 \pm 0.23 b$ & $9.76 \pm 0.08 b$ \\
\hline F. bidentis & $6.76 \pm 0.53 a$ & $0.33 \pm 0.03 a$ & $0.12 \pm 0.02 \mathrm{a}$ & $1.11 \pm 0.06 a$ & $1.56 \pm 0.08 a$ & $11.06 \pm 0.47 a$ \\
\hline
\end{tabular}

Table 4. Soil enzymatic activities of invaded and non-invaded blocks in Mikania micrantha, Chromolaena odorata and Ageratina adenophora plots, respectively.

\begin{tabular}{|c|c|c|c|c|c|c|}
\hline Treatments & $\begin{array}{l}\text { Urease } \\
(\mathrm{ug} / \mathrm{g} \cdot \mathrm{h})\end{array}$ & $\begin{array}{l}\text { Acid phosphatase } \\
\text { (mg/g.24h) }\end{array}$ & $\begin{array}{l}\text { Neutral phosphatase } \\
\text { (mg/g.24h) }\end{array}$ & $\begin{array}{l}\text { Alkaline phosphatase } \\
\text { (mg/g.24h) }\end{array}$ & $\begin{array}{l}\text { Total phosphatase } \\
\text { activity (mg/g·24h) }\end{array}$ & $\begin{array}{c}\text { Catalase } \\
(\mathrm{mg} / \mathrm{g} \cdot 24 \mathrm{~h})\end{array}$ \\
\hline CK & $15.21 \pm 1.18 c$ & $2.36 \pm 0.13 b$ & $0.71 \pm 0.03 c$ & $0.25 \pm 0.02 b$ & $3.32 \pm 0.43 b$ & $2.79 \pm 1.02 b$ \\
\hline M. micrantha & $19.11 \pm 0.36 a$ & $2.05 \pm 0.18 c$ & $0.86 \pm 0.02 b$ & $0.88 \pm 0.10 \mathrm{a}$ & $3.79 \pm 0.26 \mathrm{ab}$ & $5.44 \pm 1.12 \mathrm{a}$ \\
\hline C. odorata & $16.91 \pm 0.84 b$ & $2.87 \pm 0.08 \mathrm{a}$ & $0.61 \pm 0.06 c$ & $0.26 \pm 0.07 b$ & $3.74 \pm 0.18 \mathrm{ab}$ & $3.08 \pm 0.79 b$ \\
\hline A. adenophora & $14.49 \pm 0.95 c$ & $2.78 \pm 0.12 \mathrm{a}$ & $1.01 \pm 0.09 a$ & $0.26 \pm 0.06 b$ & $4.05 \pm 0.16 a$ & $3.39 \pm 1.30 b$ \\
\hline
\end{tabular}


The PCR-DGGE profiles revealed a difference in the AM fungal communities between the three invasive Asteraceae plants and their corresponding native soils in the Yunnan ecosystem (Figure 2). The Cs between soil invaded by C. odorata and native soil was 64\%, followed by M. micrantha (60\%), and A. adenophora (56\%). A dendrogram created using hierarchical clustering analysis showed all samples clustered into two main groups with similarity of 0.56 . One group included soils invaded by $M$. micrantha (lanes 4-6), those invaded by $C$. odorata, and native soil (Figure 2). Based on the Cs, A. adenophora had the greatest effect on the AM fungal community in native soil. The highest values for diversity, species richness, and evenness of AM fungi were measured in soils with A. adenophora (averages of 2.69, 25.33 and 0.83 , respectively, $P<0.05$ ), followed by $C$. odorata, but no significant differences were detected between $C$. odorata and the control (Table 6).

\subsection{Correlation Analysis between AM Fungal Diversity and Environmental Variables}

As shown in Table 7, correlation analysis of AM fungal community structure and soil physiochemical properties revealed that fungal abundance was significantly positively correlated with urease and catalase activities, but significantly negatively correlated with levels of soil organic carbon and phosphatase activities. The values for AM fungal diversity were significantly positively correlated with soil organic carbon, total $\mathrm{N}, \mathrm{NH}_{4}^{+}-\mathrm{N}$, and

Table 5. Shannon-Wiener index $(H)$, richness $(S)$ and evenness $(E)$ of soil AM fungi in Flaveria bidentis invaded plots.

\begin{tabular}{cccc}
\hline Treatments & $S$ & $H$ & $E$ \\
\hline CK & $27.67 \pm 2.08 \mathrm{a}$ & $2.23 \pm 0.08 \mathrm{~b}$ & $0.67 \pm 0.01 \mathrm{~b}$ \\
F. bidentis & $27.67 \pm 1.53 \mathrm{a}$ & $2.52 \pm 0.09 \mathrm{a}$ & $0.76 \pm 0.02 \mathrm{a}$ \\
\hline
\end{tabular}

Table 6. Shannon-Wiener index $(H)$, richness $(S)$ and evenness $(E)$ of soil AM fungi in Yunnan.

\begin{tabular}{|c|c|c|c|}
\hline Treatments & $S$ & $H$ & $E$ \\
\hline CK & $21.33 \pm 0.58 c$ & $2.38 \pm 0.08 b$ & $0.78 \pm 0.02 b$ \\
\hline M. micrantha & $19.67 \pm 1.16 b c$ & $2.37 \pm 0.11 b$ & $0.80 \pm 0.02 b$ \\
\hline C. odorata & $22.67 \pm 0.58 b$ & $2.50 \pm 0.02 b$ & $0.80 \pm 0.01 b$ \\
\hline A. adenophora & $25.33 \pm 2.31 \mathrm{a}$ & $2.69 \pm 0.05 a$ & $0.83 \pm 0.01 a$ \\
\hline
\end{tabular}

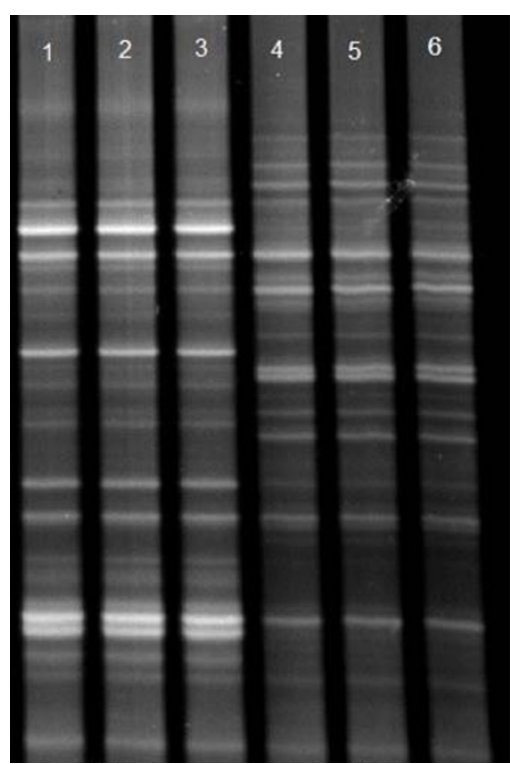

(a)

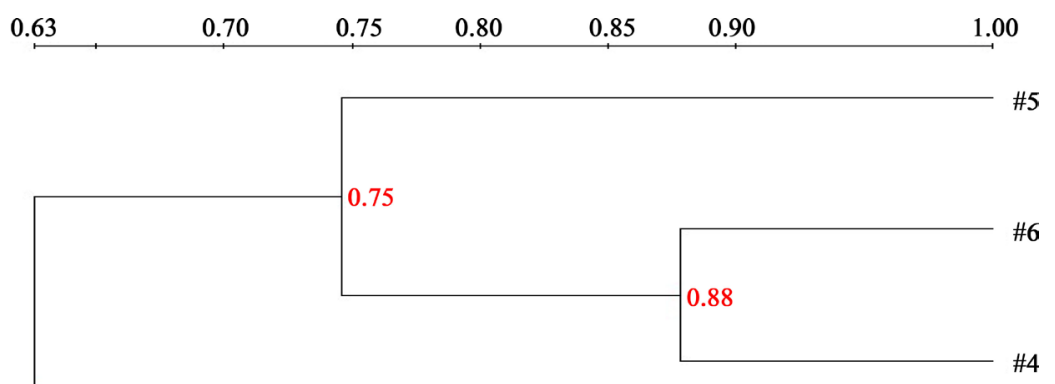

0.63

Figure 1. PCR-DGGE fingerprinting (a) and dendrogram using UPGMA (b) according to the Cs calculated on the basis of PCR-DGGE profiles of AM fungal communities in the soils invaded by F. bidentis (lane 1-3) and native soils (lane 4-6) of AM fungi in Hebei. 


$$
0.56
$$

0.70

0.80

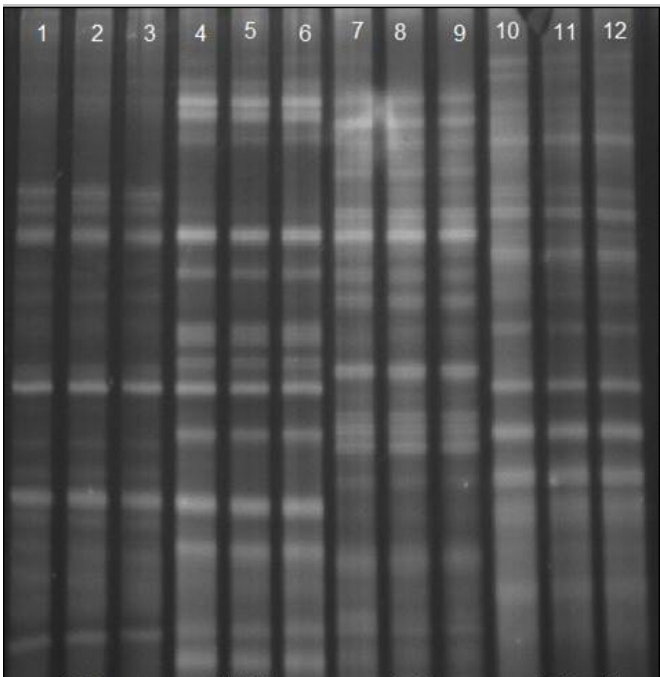

(a)

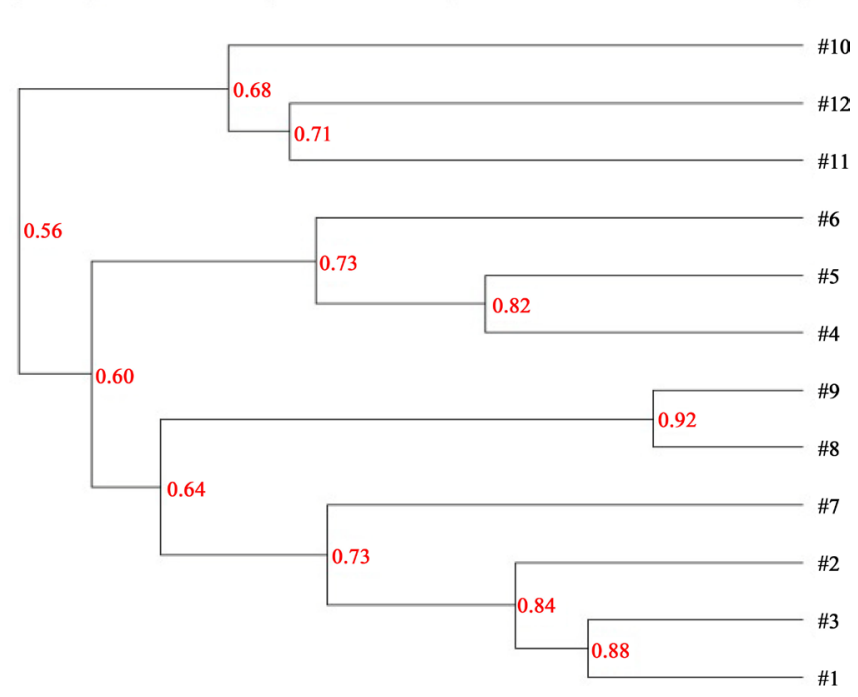

(b)

Figure 2. PCR-DGGE fingerprinting (a) and dendrogram using UPGMA (b) according to the Cs calculated on the basis of PCR-DGGE profiles of AM fungal communities in the soils invaded by M. micrantha (lane 4-6), by C. odorata (lane 7-9), by $A$. adenophora (lane 10-12) and native soils (lane 1-3) of AM fungi in Yunnan, respectively.

Table 7. Correlation analysis of soil AM fungi diversity index with soil physio-chemical parameters.

\begin{tabular}{ccccccccccc}
\hline Indexes & $\mathrm{pH}$ & $\begin{array}{c}\text { Organic matter } \\
(\mathrm{g} / \mathrm{kg})\end{array}$ & $\begin{array}{c}\text { Total N } \\
(\mathrm{g} / \mathrm{kg})\end{array}$ & $\begin{array}{c}\mathrm{NH}_{4}^{+}-\mathrm{N} \\
(\mathrm{mg} / \mathrm{kg})\end{array}$ & $\begin{array}{c}\mathrm{NO}_{3}^{-}-\mathrm{N} \\
(\mathrm{mg} / \mathrm{kg})\end{array}$ & $\begin{array}{c}\text { Total P } \\
(\mathrm{g} / \mathrm{kg})\end{array}$ & $\begin{array}{c}\text { Available P } \\
(\mathrm{mg} / \mathrm{kg})\end{array}$ & Urease & Phosphatase & Catalase \\
\hline$S$ & $0.502^{* 1)}$ & $-0.558^{*}$ & -0.468 & -0.467 & $0.470^{*}$ & $0.708^{* *}$ & 0.231 & $0.841^{* *}$ & $-0.556^{*}$ & $0.659^{* *}$ \\
$H$ & -0.460 & $0.526^{*}$ & $0.585^{*}$ & $0.625^{*}$ & 0.103 & -0.354 & $-0.709^{* *}$ & 0.227 & $0.555^{*}$ & -0.308 \\
$E$ & $-0.713^{* *}$ & $0.814^{* *}$ & $0.822^{* *}$ & $0.825^{* *}$ & -0.195 & $-0.756^{* *}$ & $-0.481^{*}$ & $0.736^{* *}$ & $0.853^{* *}$ & $0.680^{* *}$ \\
\hline
\end{tabular}

Data with $^{*}$ and ${ }^{* *}$ are indicating significantly correlated at $P=0.05$ and $P=0.01$, respectively.

phosphatase activities. The values for the evenness index of the AM fungal community showed a highly significant positive correlation with soil organic carbon, total $\mathrm{N}, \mathrm{NH}_{4}^{+}-\mathrm{N}$, urease, phosphatase, and catalase activities. Conversely, total $\mathrm{P}$ and available $\mathrm{P}$ were negatively correlated with almost all AM fungal parameters except for abundance.

\section{Discussion}

Invasion by alien plants can increase or decrease soil fertility [22]. These changes will affect competitive relationships between exotic and native species, and likely promote further invasion by invasive species [23]. Our research showed that apart from $M$. micrantha, the three invasive Asteraceae led to significant changes in soil ecosystems, and the direction of impacts was relatively consistent, suggesting that the soil $\mathrm{N}$ and $\mathrm{P}$ cycles changed upon plant invasion. Invasion by three Asteraceae, A. adenophora, C. odorata, and F. bidentis increased the $\mathrm{N}$ pool, and also lowered soil $\mathrm{pH}$ and $\mathrm{P}$ availability in the soil.

As the Asteraceae are typical mycorrhizal symbionts, AM fungi may be involved in the influence of these Asteraceae on the $\mathrm{N}$ cycle [24]. Plant invasion promoted an increase in soil $\mathrm{N}$, and a closer relationship was found between the AM fungal community structure and ammonium than with nitrate. There is evidence that AM fungi preferentially absorb ammonia rather than other forms of $\mathrm{N}$ [25]. The absorption and transfer rate of ammonia in several external hyphae of AM fungi was more than ten times that of nitrates [25] [26]. Typically, nitrates have high mobility in soils, and can quickly reach plant roots through diffusion [27], while ammonia is likely to be absorbed by soil colloids, has poor mobility and is possibly deficient in the rhizosphere. The external hyphae of AM fungi can extend the surface area of root absorption and allow plants to acquire more ammonia. 
This suggests that the ecological significance of AM fungi may also be in the exploitation of pulses in ammonia availability in the soil environment [24].

In addition, AM fungi play an important role in the ability of plants to absorb nutrients from soil [7]. They can, for example, efficiently help P absorption by Spartina alterniflora [28]. The decreased total P in soil invaded by Asteraceae, and the substantial reduction in available $\mathrm{P}$ in soil at sites where the other three Asteraceae were present (not M. micrantha), is consistent with the findings of Zhang et al. (2010) in relation to F. bidentis. Jeffries et al. [29] also verified a higher infection rate of AM fungi when there were low P levels in soil. Infection by a large number of AM fungal hyphae expands the surface area of root systems, reduces the distance for nutrient absorption by the roots, and improves spatial effectiveness of $\mathrm{P}$ in soil. Hyphae can partially replace the absorptive function of root systems [30], and increase the capacity of plants to absorb P. This might also explain why available $\mathrm{P}$ in invaded soils dropped substantially. Jiang et al. [31] maintained that A. adenophora strongly absorbs $\mathrm{P}$ in soils and limits the growth of other plants, thus outcompeting native species. The role of AM fungi in improving absorption of $\mathrm{P}$ has also been suggested by studies of other invasive plants, such as spotted knapweed [32]. The impacts of AM fungal infection on Asteraceae root systems and changes in community structure on the P cycle, as well as resultant changes in the competitive patterns of plants may play an important role in the ecosystem function.

AM fungi can directly influence the chemical properties of soil by secreting $\mathrm{H}^{+}$and some acidic compounds, and improving nutrient availability [7], which corroborates with the decrease in $\mathrm{pH}$ with Asteraceae species studied except for M. micrantha. Ezawa et al. [33] demonstrated that the invader Gigaspora margarita activated both acid and alkaline phosphatases, but $\mathrm{P}$ availability in mycorrhizal plants is typically higher than that in non-mycorrhizal plants. In our experiment, significantly increased phosphatase activity in the soil around invasive Asteraceae was remarkably correlated with the diversity of AM fungi, thus affecting the $\mathrm{P}$ cycle.

Higher diversity of AM fungi was detected in the soils invaded by A. adenophora than in the soils of the other invasive species. It is well acknowledged that AM fungi do not possess absolute specificity, but to some extent display host preferences [34]. Some AM fungi will not colonize the roots of certain plant species, or even germinate in response to the roots of certain plant species [35]. Evidence suggested that the more closely related are two co-occurring plants (e.g., A. adenophora and C. odorata), the more dissimilar are their AM fungal communities, and this might be due to the belowground niche partitioning of the AM fungal community. Other studies of plant-AM fungal associations reported similar findings [36] [37]. This might help to explain the coexistence of co-occurring species, especially in the presence of interspecific competition [38]. As AM fungi effectively increase resource acquisition, plants (such as M. micrantha, A. adenophora, and C. odorata) that associate with distinct AM fungi may experience enhanced functional complementarity relative to other species [37]. Also, this association might enable the more complete use of available resources and an overall increase in plant productivity [14]. Exploring further why the shifting patterns of AM fungal communities diverge from those of other Asteraceae species constitutes an interesting prospect for additional research.

In contrast with our expectations, the pattern of impact of M. micrantha on invaded soils differed somewhat from that of the other three Asteraceae. Mikania possesses many of the biological characteristics associated with successful invasive plant species [39]; it has a smothering habit, grows very fast, develops adventitious roots in each vine node as an asexual reproduction strategy, and also produces allelochemicals that mainly leach from stems [40]. It was speculate, therefore, that M. micrantha is more reliant on aboveground competition for invasion of new habitats. Owing to this difference in invasion strategies between M. micrantha and the other Asteraceae studied, impacts on the properties of invaded soil and the microbial flora also vary; highlighting the importance of the biological characteristics of each invasive species.

\section{Conclusion}

In summary, with the exception of invasion by M. micrantha, Asteraceae invasion leads to significant changes in soil ecosystems in similar pattern, suggesting that $\mathrm{N}$ and $\mathrm{P}$ cycles in invaded soil change upon plant invasion. Pulses in ammonia and a drop in available P seem well correlated with AM fungal diversity. Moreover, intrafamilial comparisons of the Asteraceae have shown that close relatives tend to host more divergent AM fungi, and that host preferences might favor co-occurring species. Thus, in the area studied, a feedback system in plant-AM fungi-soil nutrients might be one of the mechanisms underlying the success of the invasive Asteraceae, suggesting belowground plant-AM fungal associations in niche partitioning and coexistence of confamilial species. 


\section{Acknowledgements}

This research was financially supported by the Natural Science Foundation of Tianjin (12JCQNJC09800), Special Fund for Agro-scientific Research in the Public Interest (201103027) and the National Science Foundation of China (31401811).

\section{References}

[1] Xie, Y., Li, Z.Y., William, P.G. and Li, D. (2000) Invasive Species in China-An Overview. Biodiversity and Conservation, 10, 1317-1341.

[2] Weber, E., Sun, S. and Li, B. (2008) Invasive Alien Plants in China: Diversity and Ecological Insights. Biological Invasions, 10, 1411-1429. http://dx.doi.org/10.1007/s10530-008-9216-3

[3] John, P.S. and John, M.D. (2011) Why Are Some Plant Genera More Invasive than Others? PLoS ONE, 6, 1-8.

[4] Chen, B.M., Peng, S.L. and Ni, G.Y. (2009) Effects of the Invasive Plant Mikania micrantha H.B.K. on Soil Nitrogen Availability through Allelopathy in South China. Biological Invasions, 11, 1291-1299. http://dx.doi.org/10.1007/s10530-008-9336-9

[5] Huangfu, C.H., Zhang, T.R., Chen, D.Q., Wang, N.N. and Yang, D.L. (2011) Residual Effects of Invasive Weed Yellowtop (Flaveria bidentis) on Forage Plants for Ecological Restoration. Allelopathy Journal, 27, 55-64.

[6] Huangfu, C.H., Li, H.Y., Chen, X.W., Liu, H.M. and Yang, D.L. (2015) The Effects of Exotic Weed Flaveria bidentis with Different Invasion Stages on Soil Bacterial Community Structures. African Journal of Biotechnology, 14, 26362643. http://dx.doi.org/10.5897/AJB2015.14658

[7] Smith, S.E., Jakobsen, I., Gronlund, M. and Smith, F.A. (2011) Roles of Arbuscular Mycorrhizas in Plant Phosphorus Nutrition: Interactions between Pathways of Phosphorus Uptake in Arbuscular Mycorrhizal Roots Have Important Implications for Understanding and Manipulating Plant Phosphorus Acquisition. Plant Physiology, 156, 1050-1057. http://dx.doi.org/10.1104/pp.111.174581

[8] Helgason, T., Merryweather, J.W., Denison, J., Wilson, P., Young, J.P.W. and Fitter, A.H. (2002) Selectivity and Functional Diversity in Arbuscular Mycorrhizas of Co-Occurring Fungi and Plants from a Temperate Deciduous Woodland. Journal of Ecology, 90, 371-384. http://dx.doi.org/10.1046/j.1365-2745.2001.00674.x

[9] Moora, M., Öpik, M., Sen, R. and Zobel, M. (2004) Native Arbuscular Mycorrhizal Fungal Communities Differentially Influence the Seedling Performance of Rare and Common Pulsatilla Species. Functional Ecology, 18, 554-562. http://dx.doi.org/10.1111/j.0269-8463.2004.00876.x

[10] Uibopuu, A., Moora, M., Saks, U., Daniell, T., Zobel, M. and Öpik, M. (2009) Differential Effect of Arbuscular Mycorrhizal Fungal Communities from Ecosystems along Management Gradient on the Growth of Forest Understorey Plant Species. Soil Biology and Biochemistry, 41, 2141-2146. http://dx.doi.org/10.1016/j.soilbio.2009.07.026

[11] Zhang, T.R., Huangfu, C.H., Bai, X.M. and Yang, D.L. (2010) Effects of Flaveria bidentis Invasion on Soil Nutrient Contents and Enzyme Activities. Chinese Journal of Ecology, 29, 1353-1358.

[12] Pringle, A., Bever, J.D., Gardes, M., Parrent, J.L., Rillig, M.C. and Klironomos, J.N. (2009) Mycorrhizal Symbioses and Plant Invasions. Annual Review of Ecology and Systematics, 40, 699-715. http://dx.doi.org/10.1146/annurev.ecolsys.39.110707.173454

[13] Shah, M.A., Reshi, Z.A. and Khasa, D.P. (2009) Arbuscular Mycorrhizas: Drivers or Passengers of Alien Plant Invasion. Botanical Review, 75, 397-417. http://dx.doi.org/10.1007/s12229-009-9039-7

[14] Montesinos-Navarro, A., Segarra-Moragues, J.G., Valiente-Banuet, A. and Verdú, M. (2012) Plant Facilitation Occurs between Species Differing in Their Associated Arbuscular Mycorrhizal Fungi. New Phytologist, 196, 835-844. http://dx.doi.org/10.1111/j.1469-8137.2012.04290.x

[15] Zhu, H.H., Yao, Q., Sun, X.T. and Hu, Y.L. (2007) Colonization, ALP Activity and Plant Growth Promotion of Native and Exotic Arbuscular Mycorrhizal Fungi at Low pH. Soil Biology and Biochemistry, 39, 942-950. http://dx.doi.org/10.1016/j.soilbio.2006.11.006

[16] Avio, L., Castaldini, M., Fabiani, A., Bedini, S., Sbrana, C., Turrini, A. and Giovannetti, M. (2013) Impact of Nitrogen Fertilization and Soil Tillage on Arbuscular Mycorrhizal Fungal Communities in a Mediterranean Agroecosystem. Soil Biology and Biochemistry, 67, 285-294. http://dx.doi.org/10.1016/j.soilbio.2013.09.005

[17] Hart, M.M., Reader, R.J. and Klironomos, J.N. (2003) Plant Coexistence Mediated by Arbuscular Mycorrhizal Fungi. Trends in Ecology \& Evolution, 18, 418-423. http://dx.doi.org/10.1016/S0169-5347(03)00127-7

[18] Hausmann, N.T. and Hawkes, C.V. (2009) Plant Neighborhood Control of Arbuscular Mycorrhizal Community Composition. New Phytologist, 183, 1188-1200. http://dx.doi.org/10.1111/j.1469-8137.2009.02882.x

[19] Kowalchuk, G.A., de Souza, F.A. and van Veen, J.A. (2002) Community Analysis of Arbuscular Mycorrhizal Fungi 
Associated with Ammophila arenaria in Dutch Coastal Sand Dunes. Molecular Ecology, 11, 571-581. http://dx.doi.org/10.1046/j.0962-1083.2001.01457.x

[20] Cornejo, P., AzcÓn-Aguilar, C., Barea, J.M. and Ferrol, N. (2004) Temporal Temperature Gradient Gel Electrophoresis (TTGE) as a Tool for the Characterization of Arbuscular Mycorrhizal Fungi. FEMS Microbiology Letters, 241, 265270. http://dx.doi.org/10.1016/j.femsle.2004.10.030

[21] Long, L.K., Yao, K., Guo, J., Yang, R.H., Huang, Y.H. and Zhu, H.H. (2010) Molecular Community Analysis of Arbuscular Mycorrhizal Fungi Associated with Five Selected Plant Species from Heavy Metal Polluted Soils. European Journal of Soil Biology, 46, 288-294. http://dx.doi.org/10.1016/j.ejsobi.2010.06.003

[22] Liao, C.Z., Peng, R.H., Luo, Y.Q., Zhou, X.H., Wu, X.W., Fang, C.M., Chen, J.K. and Li, B. (2008) Altered Ecosystem Carbon and Nitrogen Cycles by Plant Invasion: A Meta-Analysis. New Phytologist, 177, 706-714. http://dx.doi.org/10.1111/j.1469-8137.2007.02290.x

[23] Ehrenfeld, J.G. (2003) Effects of Exotic Plant Invasions on Soil Nutrient Cycling Processes. Ecosystems, 6, 503-523. http://dx.doi.org/10.1007/s10021-002-0151-3

[24] Veresoglou, S.D., Sen, R., Mamolos, A.P. and Veresoglou, D.S. (2011) Plant Species Identity and Arbuscular Mycorrhizal Status Modulate Potential Nitrification Rates in Nitrogen-Limited Grassland Soils. Journal of Ecology, 99, 13391349. http://dx.doi.org/10.1111/j.1365-2745.2011.01863.x

[25] Hawkins, H. and George, E. (2001) Reduced ${ }^{15}$ N-Nitrogen Transport through Arbuscular Mycorrhizal Hyphae to Triticumestivum L. Supplied with Ammonium vs Nitrate Nutrition. Botany, 87, 303-311. http://dx.doi.org/10.1006/anbo.2000.1305

[26] Yoko, T. and Katsuya, Y. (2005) Nitrogen Delivery to Maize via Mycorrhizal Hyphae Depends on the Form of N Supplied. Plant Cell and Environment, 28, 1247-1254. http://dx.doi.org/10.1111/j.1365-3040.2005.01360.x

[27] Tinker, P.B.H. and Nye, P.H. (2000) Solute Transport in the Rhizosphere. Oxford University Press, Oxford.

[28] McHugh, J.M. and Dighton, J. (2004) Influence of Mycorrhizal Inoculation, Inundation Period, Salinity and Phosphorus Availability on the Growth of Two Salt Marsh Grasses, Spartina alterniflora Lois. And Spartina cynosuroides (L.) Roth in Nursery Systems. Restoration Ecology, 12, 533-545. http://dx.doi.org/10.1111/j.1061-2971.2004.03109.x

[29] Jeffries, P., Gianinazzi, S., Sperotto, S., Turnau, K. and Barea, J. (2003) The Contribution of Arbuscular Mycorrhizal Fungi Sustainable Maintenance of Plant Health and Fertility. Biology and Fertility of Soils, 37, 1-16.

[30] Vance, C.P., Uhde-Stone, C. and Allan, D.L. (2003) Phosphorus Acquisition and Use: Critical Adaptations by Plants for Securing a Nonrenewable Resource. New Phytologist, 157, 423-447. http://dx.doi.org/10.1046/j.1469-8137.2003.00695.x

[31] Jiang, Z.L., Liu, W.X., Wan, F.H. and Li, Z.Y. (2008) Effects of Ageratina adenophora (Spreng.) Invasion on Soil Nutrient Properties and Their Seasonal Dynamics. Journal of Agro-Environment Science, 27, 267-272.

[32] Zabinski, C.A., Quinn, L. and Callaway, R.M. (2002) Phosphorus Uptake, Not Carbon Transfer, Explains Arbuscular Mycorrhizal Enhancement of Centaurea maculosa in the Presence of Native Grassland Species. Function Ecology, 16, 758-765. http://dx.doi.org/10.1046/j.1365-2435.2002.00676.x

[33] Ezawa, T., Saito, M. and Yoshida, T. (1995) Comparison of Phosphatase Localization in the Intraradial Hyphae of Arbuscular Mycorrhizal Fungi, Glomus Spp and Gigaspora Spp. Plant and Soil, 176, 57-63. http://dx.doi.org/10.1007/BF00017675

[34] Sanders, I.R. (2003) Preference, Specificity and Cheating in the Arbuscular Mycorrhizal Symbiosis. Trends in Plant Science, 8, 143-145. http://dx.doi.org/10.1016/S1360-1385(03)00012-8

[35] Clapp, J.P., Helgason, T., Daniell, T.J. and Young, J.P.W. (2002) Genetic Studies of the Structure and Diversity of Arbuscular Mycorrhizal Fungal Communities. In: van der Heijden, M.G.A. and Sanders, I.R., Eds., Mycorrhizal Ecology, Springer-Verlag, Berlin, 201-224.

[36] Veresoglou, S.D. and Rillig, M.C. (2014) Do Closely Related Plants Host Similar Arbuscular Mycorrhizal Fungal Communities? A Meta-Analysis. Plant and Soil, 377, 395-406. http://dx.doi.org/10.1007/s11104-013-2008-2

[37] Reinhart, K.O. and Anacker, B.L. (2014) More Closely Related Plants Have More Distinct Mycorrhizal Communities. AoB Plants, 6, plu051. http://dx.doi.org/10.1093/aobpla/plu051

[38] Aanderud, Z.T. and Bledsoe, C.S. (2009) Preferences for ${ }^{15} \mathrm{~N}$-Ammonium, ${ }^{15} \mathrm{~N}$-Nitrate, and ${ }^{15} \mathrm{~N}$-Glycine Differ among Dominant Exotic and Subordinate Native Grasses from a California Oak Woodland. Environmental and Experimental Botany, 65, 205-209. http://dx.doi.org/10.1016/j.envexpbot.2008.10.003

[39] Yang, Q.H., Feng, H.L. and Ye, W.H. (2003) An Investigation of the Effects of Environmental Factors on the Flowering and Seed Setting of Mikania micrantha H.B.K. Journal of Tropical and Sub-Tropical Botany, 11, 123-126.

[40] Zhang, M.X., Ling, B., Kong, C.H., Zhao, H. and Pang, X.F. (2002) Allelopathic Potential of Volatile Oil from Mikania micrantha. Chinese Journal of Applied Ecology, 13, 1300-1302. 